NBER WORKING PAPER SERIES

QUALITY-CONSISTENT ESTIMATES OF INTERNATIONAL RETURNS TO SKILL

\author{
Eric A. Hanushek \\ Lei Zhang \\ Working Paper 12664 \\ http://www.nber.org/papers/w12664
}

NATIONAL BUREAU OF ECONOMIC RESEARCH

1050 Massachusetts Avenue

Cambridge, MA 02138

November 2006

This research has been supported by the Packard Humanities Institute. We thank Statistics Canada and Yvan Clermont, Richard Desjardins, Scott Murray, and Albert Tuijnman for helping to provide us with the data., The views expressed herein are those of the author(s) and do not necessarily reflect the views of the National Bureau of Economic Research.

(C) 2006 by Eric A. Hanushek and Lei Zhang. All rights reserved. Short sections of text, not to exceed two paragraphs, may be quoted without explicit permission provided that full credit, including $\odot$ notice, is given to the source. 
Quality-Consistent Estimates of International Returns to Skill

Eric A. Hanushek and Lei Zhang

NBER Working Paper No. 12664

November 2006

JEL No. I2,J2

\begin{abstract}
$\underline{\text { ABSTRACT }}$
Returns to education are traditionally estimated in a Mincer wage equation from the variation in schooling for a cross-section of individuals of different ages. Because individuals receive education at different time periods, when the quality of their education may not be identical, this method leads to an overor under-estimation of the return to education of a given quality depending on how education quality evolves over time. This quality issue interacts with ability bias from self-selection into schooling and is particularly problematic when comparing returns across different countries. Using microdata from the International Adult Literacy Survey, we construct quality adjusted measures of schooling attained at different time periods and use these along with international literacy test information to estimate returns to skills for 13 countries. Estimated returns to quality-adjusted education are considerably higher than the traditional estimate for most countries, but these are offset to varying degrees by selection biases on ability. The combined corrections alter significantly the pattern of returns to schooling and skill seen from naïve Mincer wage equations.
\end{abstract}

Eric A. Hanushek

Hoover Institution

Stanford University

Stanford, CA 94305-6010

and NBER

hanushek@stanford.edu

Lei Zhang

Clemson University

Department of Economics

Clemson, SC 29634

zlei@clemson.edu 


\section{Quality-Consistent Estimates of International Returns to Skill}

By Eric A. Hanushek and Lei Zhang

\section{Introduction}

Much has been made of international differences in rates of return to schooling (e.g., Psacharopoulos (1994), Harmon, Oosterbeek, and Walker (2003), Psacharopoulos and Patrinos (2004)), but a parallel literature has highlighted potential problems with the standard Mincerian estimation approach (e.g., Card (1999)). The most commonly discussed problem is that higher ability individuals may systematically choose more schooling, leading to an upward bias in the estimated return to schooling. Less commonly, consideration is given to differences in student and school quality, which would introduce systematic measurement error in schooling itself. Correcting for measurement and selection issues is especially important for international comparisons of returns to skills, but it also enters into the analyses of individual countries.

In the classical Mincer wage equation, the return to education is estimated making use of the variation in years of schooling of a cross-section of individuals of varying ages. The presumption is that, say, the cross-sectional earnings of a forty-five year old secondary school graduate is a good indication of what a twenty-five year old graduate can expect in 20 years. Prior attention has been given to the possibility that patterns of technological change and productivity growth could systematically alter the future labor market returns to schooling (Murphy and Welch (1992), Katz and Murphy (1992)). But, limited attention has been given to the measurement of schooling itself. Two circumstances have been considered: measurement error due to misreporting of school 
attainment on surveys ${ }^{2}$ and the possibility that a GED certificate is not the same as a regular high school diploma. ${ }^{3}$

Two other aspects of the measurement of schooling may, however, be more important - particularly in an international context. First, if the quality of schooling obtained differs across time, the estimated average return to schooling of different qualities may over- or under-estimate the return to education for an individual depending on how schooling quality has changed over time. Second, if the high school graduates of different times were drawn from a different part of the ability distribution because of changes in school enrollment and completion rates, the estimated return to graduates can clearly be biased.

Accounting for secular changes in school quality has been difficult within most available cross-sectional or panel data sets, because there are no data that track quality. While some attempts rely on changes in measurable inputs - such as spending or pupilteacher ratios - the uncertain verification of these measures of quality has led to limited acceptance. ${ }^{4}$ Here we rely on external information about student cognitive skills for individuals educated during different periods to provide information on changing school quality.

The International Adult Literacy Survey (IALS) not only provides test information on skills for a broad age distribution but also includes data on labor market outcomes in a number of different countries, thus permitting direct investigation both of changes in school quality and of the returns to skill within different economies.

\footnotetext{
${ }^{2}$ From their sample of twins, Ashenfelter and Krueger (1994) find that measurement error is more important than selection problems in the estimation of the returns to schooling.

${ }^{3}$ See Cameron and Heckman (1993), Tyler, Murnane, and Willett (2000).

${ }^{4}$ This debate can be traced through Card and Krueger (1992), Heckman, Layne-Farrar, and Todd (1996), and Hanushek, Rivkin, and Taylor (1996); see also Hanushek (2003).
} 
We first construct a quality-adjusted years of schooling measure for individuals of 13 countries separately. This quality adjustment standardizes schooling obtained at different points in time based on the relative contributions of schooling to cognitive skills. For almost all countries in our sample, our analysis suggests that the contributions of additional schooling to literacy skills are higher for more recent cohorts. This is consistent with the average quality of schooling improving over time and in general implies that the simple Mincer returns underestimate the value of an additional year of schooling today. Compared to other countries, however, the adjustment of quality of education in the US is less important, reflecting the general finding that school quality in the US has been relatively stable for several decades. ${ }^{5}$

While estimating the returns to cognitive skills in the U.S. has been previously possible, largely because of panel data sets with labor market experiences, comparable international estimates have been lacking. ${ }^{6}$ This paper exploits the IALS data with its information about a broad set of workers to expand significantly the international data base on returns to skills and how these returns may be affected by the different aspects of the underlying economies.

We also investigate the potential impact of statistical discrimination. If employers differentiate among young workers largely on the basis of easily observable characteristics such as schooling, the return to the easily observed variables should fall, ceteris paribus, as employers learn more precisely about productivity. Using NLSY79 data, Altonji and Pierret (2001) find support of this proposition from US individuals

\footnotetext{
${ }^{5}$ See Hanushek (2003); National Center for Education Statistics (2005).

${ }^{6}$ Three recent U.S. studies provide direct (and quite consistent) estimates of the impact of test performance on earnings using different panel data sets (Mulligan (1999); Murnane, Willett, Duhaldeborde, and Tyler (2000); Lazear (2003)).
} 
between 14 and 35 years of age. We test this hypothesis across countries and for a wider range of age groups. We find little support for such labor market outcomes in most of our sampled countries.

The paper is organized as follows. Section 2 describes the underlying international data. Section 3 sets up and estimates the empirical model of the quality of schooling at different time periods and obtains a quality-adjusted years of schooling measure. Section 4 presents the estimation of returns to quality-adjusted years of schooling and to cognitive skills. In both sections, we discuss the similarities and differences across countries.

\section{The IALS Data}

The primary data source is the International Adult Literacy Survey (IALS), conducted by the OECD. Twenty-three countries and regions participated in one of three different waves of surveys conducted in 1994, 1996 and $1998 .{ }^{7}$ IALS is designed to compare individual literacy skills within and across countries. Representative samples of adults between 16 and 65 years of age were given a series of literacy tests in the language of their country of residence. The literacy skill measures were supplemented by variables measuring other individual characteristics, such as age, education, employment, and earnings.

Note that the oldest sampled individuals were born around 1930, while the youngest in the sample (16-year-olds) were born around $1980 .{ }^{8}$ The sample, heavily weighted toward European countries, thus has significant numbers attending school

\footnotetext{
${ }^{7}$ A technical description of the survey and data can be found in Murray, Kirsch, and Jenkins (1997). The data are available from Statistics Canada: http://www.statcan.ca/english/freepub/89-588-XIE/about.htm

${ }^{8}$ For reasons described below, much of our analysis is confined to the 25-65 age group.
} 
around World War II and during postwar reconstruction - suggesting that school quality may differ significantly for individuals with the same attainment but educated at different times within each country.

IALS provides measurement of cognitive skills in three different areas. Prose literacy measures the knowledge and skills needed to understand and use information from texts including editorials, news stories, poems, and fiction. Document literacy measures the knowledge and skills required to locate and use information contained in various formats, including job applications, payroll forms, transportation schedules, maps, tables, and graphics. Quantitative literacy measures the knowledge and skills required to apply arithmetic operations, either alone or sequentially, to numbers embedded in printed materials, such as balancing a checkbook, calculating a tip, completing an order form, or determining the amount of interest on a loan from an advertisement. The literacy scores range on a scale from 0 to 500 points for each area. Since the literacy scores are highly correlated with each other, we use the average of the scores in the analysis.

Table 1 provides summary statistics for the participating countries; the 13 countries in bold included continuous earnings measures and are included in the subsequent labor market analysis. ${ }^{9}$ Sample sizes range from 2,062 in Germany to 5,660 in Canada. On the literacy tests, individuals score an average of 267 points with a standard deviation of 60 points. Sweden and Norway have the highest average, while Chile is at the bottom. The final three columns show the considerable variation not only in average school attainment but also the distribution. For example, Chile and the Czech

\footnotetext{
${ }^{9}$ As discussed below, Canada, Slovenia, and the Italian region of Switzerland have continuous wage measures but are missing other crucial data needed for the full estimation.
} 
Table 1. Descriptive Statistics for IALS Sample Countries

[Bold indicates countries used in subsequent earnings analysis]

\begin{tabular}{|c|c|c|c|c|c|c|}
\hline Country & observations & $\begin{array}{c}\text { average } \\
\text { score }\end{array}$ & $\begin{array}{l}\text { Standard } \\
\text { deviation }\end{array}$ & $\begin{array}{c}\text { years of } \\
\text { schooling }\end{array}$ & $\begin{array}{c}\text { less than } \\
\text { upper } \\
\text { secondary, } \\
\%\end{array}$ & $\begin{array}{c}\text { tertiary and } \\
\text { above, } \%\end{array}$ \\
\hline$\overline{\text { All }}$ & 64196 & 267.0 & 60.2 & 11.8 & 42.1 & 22.8 \\
\hline Belgium $^{2}$ & 2261 & 287.5 & 50.6 & 12.7 & 39.6 & 33.5 \\
\hline Canada $^{1}$ & 5660 & 258.9 & 64.8 & 11.3 & 45.5 & 25.8 \\
\hline Chile $^{3}$ & 3583 & 208.3 & 57.9 & 9.0 & 64.3 & 15.7 \\
\hline Czech Republic $^{3}$ & 3132 & 286.3 & 45.5 & 12.8 & 47.0 & 15.8 \\
\hline Denmark $^{3}$ & 3026 & 290.7 & 39.8 & 12.7 & 27.6 & 26.1 \\
\hline Finland $^{3}$ & 2928 & 289.6 & 47.2 & 12.3 & 31.5 & 19.9 \\
\hline Germany $^{1}$ & 2062 & 283.9 & 42.7 & 11.4 & 59.1 & 15.8 \\
\hline Great Britain $^{2}$ & 3811 & 267.0 & 61.0 & 12.3 & 55.7 & 25.2 \\
\hline Hungary $^{3}$ & 2593 & 250.9 & 47.7 & 11.5 & 32.6 & 15.4 \\
\hline Ireland $^{1}$ & 2423 & 261.7 & 56.9 & 10.3 & 54.2 & 17.3 \\
\hline Italy $^{3}$ & 2974 & 252.8 & 57.9 & 11.5 & 43.9 & 13.3 \\
\hline Netherlands ${ }^{1}$ & 3090 & 284.4 & 45.2 & 12.7 & 44.3 & 24.2 \\
\hline New Zealand ${ }^{2}$ & 4223 & 277.9 & 51.5 & 12.3 & 43.9 & 29.7 \\
\hline Northern Ireland ${ }^{2}$ & 2907 & 265.7 & 63.2 & 12.5 & 61.5 & 21.3 \\
\hline Norway $^{3}$ & 3307 & 295.7 & 46.3 & 12.1 & 15.2 & 38.3 \\
\hline Poland $^{1}$ & 3000 & 228.7 & 64.4 & 10.9 & 63.1 & 14.4 \\
\hline Slovenia $^{3}$ & 2972 & 234.6 & 61.8 & 11.0 & 37.8 & 12.7 \\
\hline Sweden $^{1}$ & 3038 & 297.6 & 52.7 & 11.3 & 33.3 & 23.5 \\
\hline Switzerland $(F, G)^{*_{1}}$ & 2843 & 272.7 & 57.7 & 12.8 & 13.4 & 26.9 \\
\hline Switzerland (I) ${ }^{* * 3}$ & 1302 & 273.4 & 49.9 & 12.3 & 27.1 & 20.4 \\
\hline United States $^{1}$ & 3061 & 258.8 & 71.1 & 12.9 & 28.9 & 34.9 \\
\hline
\end{tabular}

${ }^{1}:$ Surveyed in 1994

2: Surveyed in 1996

3: Surveyed in 1998

*: French and German speaking Switzerland

${ }^{* *}:$ Italian speaking Switzerland 
Republic have almost identical completion of tertiary schooling (around 16 percent) but their average attainment differs by almost four years.

The literacy tests are designed to measure basic skills needed to participate fully in modern society, and it is useful to put these literacy test scores into the perspective of cognitive tests requiring deeper content knowledge and analytical skills. We compare the quantitative IALS score of individuals between 16 and 25 years of age to the 1995 TIMSS math score of students at the final year of upper secondary education, who are between 17 and 20 years of age. ${ }^{10}$ Figure 1 illustrates the relationship between TIMSS math score and young adults' quantitative literacy score. Thirteen countries are included in both IALS and TIMSS. The correlation between the average country scores is 0.77 and is significantly different from zero. ${ }^{11}$ Thus, the literacy scores appear to be a reasonable index of general levels of skills.

\section{School Quality}

The goal of the empirical analysis is to provide estimates of the returns to schooling of a given quality and to cognitive skills. Conceptually, one would follow groups of individuals with differing investments in human capital over their entire careers and observe how earnings evolve and differ. This conceptual best may not, however, be ideal, because one would not like to be restricted just to evaluating human capital investments made multiple decades earlier. An appealing analytical solution, laid out

\footnotetext{
${ }^{10}$ The Third International Mathematics and Science Study, or TIMSS, conducted in 1995 involved participation of 40 countries and followed two prior test development cycles for math and for science. It is commonly accepted as a valid test for differences in math skills and includes a variety of high level items covering calculus, probability and statistics, and geometry. See http://timss.bc.edu/timss $1995 . \mathrm{html}$. With testing in 1999 and after, TIMSS was renamed the Trends in International Mathematics and Science Study. ${ }^{11}$ The correlation is calculated for 12 countries: Czech Republic appears to be an outlier in the scatter plot. The same relationship holds when we restrict the IALS sample to the same age group as the TIMSS, but we lose Canada because it does not have an age measure. The same relationship holds for male and female separately.
} 


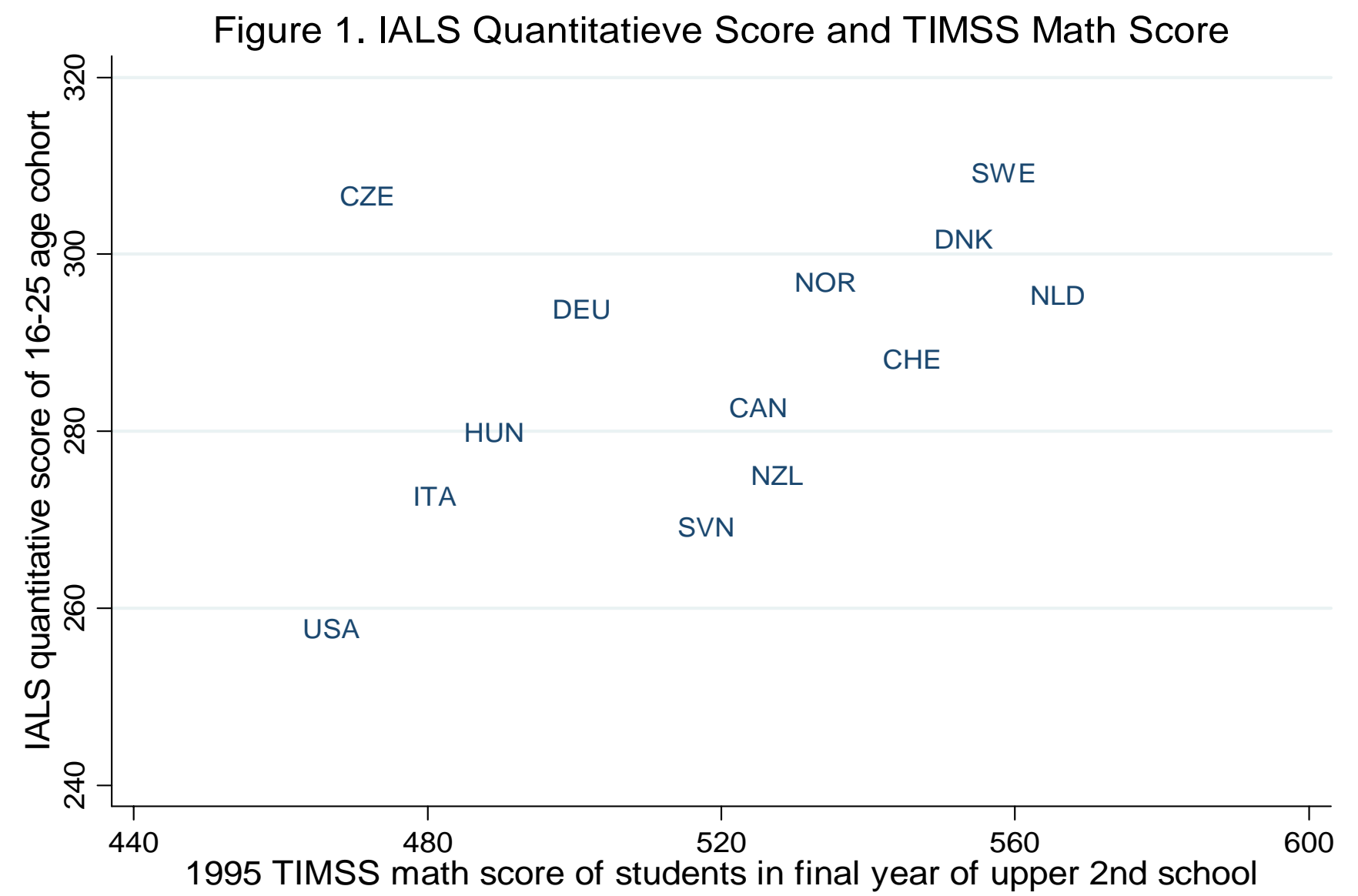

Notes: CAN stands for Canada, CHE for Switzerland, CZE for Czech Republic, DEU for Germany, DNK for Danmark, HUN for Hungary, ITA for Italy, NLD for the Netherlands, NOR for Norway, NZL for New Zealand, SVN for Slovenia, SWE for Sweden. 
clearly in Mincer $(1970,1974)$, is to use data about otherwise similar individuals who provide investment-earnings observations at different points in the life-cycle. The key question, one that has driven much of the subsequent research, is when individuals are "otherwise similar."

Our focus is ensuring that individuals are comparable in terms both of school quality and of cognitive skills. In this section, we estimate quality indices for schooling received at different time periods and adjust years of schooling with these quality indices relative to a base cohort. In the following section, we use the quality-adjusted years of schooling in a Mincer wage regression designed to estimate the return to schooling and the return to cognitive skills for this base cohort.

\subsection{Identifying Changes in School Quality}

To estimate school quality, we assume that, other things equal, an additional year of quality-equivalent schooling produces the same increment in average literacy scores. Quality of education received in different time periods for each country is derived from coefficient estimates on cohort-specific and country-specific years of schooling variable in a regression for the literacy score. Each cohort is a 10-year age group. We focus on four cohorts aged 26-35, 36-45, 46-55, and 56-65 and take the cohort aged 26-35 as the base $^{\text {cohort. }}{ }^{12}$

(1) $\quad L_{i k c}=\beta_{k c} \cdot S_{i k c}+X_{i k} \cdot \gamma_{k}+\varepsilon_{i k c}$

\footnotetext{
12 This limitation of sample to individuals over 25 is due to two factors. First, many of the 16-25 age group will still be in school, introducing sample selection biases in both the school quality analysis and the earnings analysis. Second, we lack a critical variable, the selectivity of schooling, for this youngest cohort.
} 
where $L_{i k c}$ is the literacy score of individual $i$ of country $k$ and cohort $c, S_{i k c}$ is the years of schooling of individual $i$ of country $k$ and cohort $c$, and $X_{i k}$ is a vector of country-specific control variables; $\varepsilon_{i k c}$ is a stochastic error term. $\beta_{k c}$ measures the marginal contribution to the literacy score of the schooling of cohort $c$ in country $k$.

The estimation and interpretation of $\beta_{k c}$ are complicated by the fact that the cohort-specific years-of-schooling measure reflects not only the education attainment of an individual, but also other factors that vary with time. First, average years of schooling have been continuously increasing for virtually every country over the past several decades. ${ }^{13}$ Associated with this improvement is the concern that the school and college selectivity has gone down over time. In other words, if school continuation is related to ability, people with lower innate ability have been promoted to higher schooling levels over time. Our time-specific measure of school attainment may capture not only the effects of schooling itself but also the decrease in school selectivity over time. If so, the contributions of more recent cohorts' schooling will be underestimated. We deal with this problem by including a measure for school selectivity in $X$.

Second, individuals may gain or lose skills as a result of the aging process itself. If individuals tend to lose skills because of aging, then the contributions of earlier cohorts' schooling will be underestimated, and vice versa. We include in $X$ a polynomial of age, which is not country specific, to control for this problem. This specification

\footnotetext{
${ }^{13}$ As we discuss below, these trends have been much stronger for other countries compared to the U.S. This fact shows up in the regression estimates.
} 
captures the idea that losing or gaining literacy skills due to physical and mental depreciation is a universal process. ${ }^{14}$

Third, differential learning-by-doing at the workplace across countries could enter. The questions in the literacy tests of the survey, however, concern tasks of day-today life and are not job specific. Therefore, we assume that work experience has a limited role in affecting the performance in the tests and that omitting work place learning does not bias the estimates of the contributions of schooling to the literacy skill.

Because primary-secondary schooling quality and college quality may vary over time in different manners, we also estimate Equation (1) splitting the schooling variable into two parts: years of schooling before completing high school ( $\leq 12$ years) and years of schooling after completing high school. These two variables are again country-specific and cohort-specific.

Using the youngest cohort as the base group $(\mathrm{c}=1)$, the quality-adjusted schooling for somebody in country $k$ and cohort $c$ with schooling $S_{i k c}$ is found in Equation (2):

$$
\widetilde{S}_{i k c}=S_{i k c} \cdot \frac{\beta_{k c}}{\beta_{k 1}},
$$

where the ratio $\beta_{k c} / \beta_{k 1}$ reflects the estimated quality parameters. An index greater than 1 would indicate that cohort $c$ 's schooling is of higher quality than that of the youngest cohort; therefore, each year of schooling of cohort $c$ 's would be equivalent to more than one year of the youngest cohort's schooling.

\subsection{International Patterns of School Quality Changes}

\footnotetext{
${ }^{14}$ See Smith and Marsiske (1997). The skill depreciation with the aging process could, of course, be distorted by different time patterns of nutrition and health care across countries, but we have no way to deal with this possibility.
} 
Quality indices of schooling at different time periods are derived from the estimated contributions of schooling at different time periods to the literacy skills. Understanding the pattern of school selectivity across countries, because it indicates varying ability of people with similar schooling at different times, is a first step.

We assume that in any given country, an individual of cohort $c$ who completes school level $s$ has higher ability than any individual of the same cohort who completes a school level less than $s$. If share $\omega$ of population of cohort $c$ completes at least school level $s$, then an individual of cohort $c$ that completes school level $s$ will have higher ability than share $1-\omega$ of population of the same cohort. We therefore assign $1-\omega$ as the selectivity measure for an individual $i$ of cohort $c$ who completes school level $s$. This measure is simply the lower-bound ability measure for individual $i$.

Take the United States as an example. In 1994, 86\% of individuals between ages 25 and 34 completed at least high school education, and 14\% did not finish high school. Therefore, an individual of this cohort that completed exactly high school has on average higher ability than $14 \%$ of the cohort and is assigned a selectivity index of 0.14 . Similarly, the selectivity index of an average American in this cohort that completed at least college education is 0.68 .

The Organisation for Economic Co-operation and Development (2005) provides historical information about completion of upper secondary and tertiary schooling by different age groups across countries. ${ }^{15}$ These data permit us to calculate selectivity

\footnotetext{
${ }^{15}$ Historical data come from a variety of OECD publications including various years of Education at a Glance (e.g., Organisation for Economic Co-operation and Development (2005)) and Organisation for Economic Co-operation and Development (1995). Because we use the population survey information in one year to characterize populations going to school at different time periods, we need to assume that the underlying distribution for each cohort is stable over time. This assumption may not hold if, for example, the proportion of immigrants in a cohort has changed considerably over time
} 
indices across countries for individuals of different ages. The data on completing tertiary education for some countries and some cohorts are also divided between academic and vocational-technical. ${ }^{16}$ The selectivity measures can range between 0 and 1 , with individuals completing less than upper secondary education receiving a selectivity measure of zero.

Across sampled countries and over time, the selectivity of schooling shows wide variation. Table 2 provides the selectivity measures $(1-\omega)$ for four cohorts of individuals completing upper secondary education and completing tertiary education for each country. (The top panel aggregates all tertiary schooling, while the bottom panel separates vocational-technical from academic where available). While the U.S. has seen little change in the selectivity of schooling over the four decades represented in Table 2, other countries, such as Poland and Sweden, have had dramatic changes. The strong trends toward more schooling imply that individuals from earlier cohorts have higher selectivity measures than those from younger cohorts. This changing selectivity is also more pronounced for individuals completing upper secondary education, as countries have expanded secondary education at a much faster pace than tertiary education.

The school quality regression is based on individual observations for the average literacy scores in prose, documentary, and quantitative skills (normalized to mean zero and standard deviation of one within each country). The explanatory variables of primary interest are the country- and cohort-specific years of schooling for four 10-year age

\footnotetext{
${ }^{16}$ See Annex 3 of OECD Education at a Glance for a description of the International Standard Classification of Education (ISCED). In short, type B tertiary education is generally practical-technicaloccupational oriented with a minimum duration of two years and does not prepare students for more advanced study (vocational-technical). Type A tertiary education is more theoretically oriented with a minimum duration of three years and is intended to provide sufficient qualifications for gaining entry into advanced research programs and professions with high skills requirements (adademic).
} 
Table 2. Selectivity Measures (1- $\omega$ ) for 10-year cohorts with Different Schooling Levels

(most selective $=1$ ) [Bold indicates countries used in subsequent earnings analysis]

\begin{tabular}{lcccccccc}
\hline & \multicolumn{4}{c}{ Completed upper secondary } & \multicolumn{4}{c}{ Completed 3 or more years tertiary } \\
\hline \multicolumn{1}{c}{ age } & $26-35$ & $36-45$ & $46-55$ & $56-65$ & $26-35$ & $36-45$ & $46-55$ & $56-65$ \\
\hline Canada & 0.18 & 0.21 & 0.30 & 0.47 & 0.49 & 0.51 & 0.55 & 0.69 \\
Chile & 0.45 & 0.55 & 0.65 & 0.76 & 0.89 & 0.90 & 0.91 & 0.95 \\
Czech Republic & 0.08 & 0.12 & 0.16 & 0.24 & 0.90 & 0.88 & 0.90 & 0.92 \\
Germany & 0.10 & 0.12 & 0.16 & 0.28 & 0.80 & 0.73 & 0.76 & 0.83 \\
Hungary & 0.23 & 0.27 & 0.35 & 0.69 & 0.86 & 0.86 & 0.86 & 0.90 \\
Ireland & 0.39 & 0.53 & 0.65 & 0.73 & 0.76 & 0.81 & 0.85 & 0.89 \\
Italy & 0.45 & 0.50 & 0.65 & 0.81 & 0.91 & 0.89 & 0.91 & 0.95 \\
Netherlands & 0.31 & 0.36 & 0.46 & 0.56 & 0.76 & 0.75 & 0.81 & 0.86 \\
Norway & 0.06 & 0.11 & 0.21 & 0.32 & 0.67 & 0.71 & 0.74 & 0.79 \\
Poland & 0.12 & 0.18 & 0.32 & 0.53 & 0.90 & 0.90 & 0.88 & 0.92 \\
Sweden & 0.15 & 0.22 & 0.31 & 0.48 & 0.73 & 0.70 & 0.74 & 0.83 \\
Switzerland & 0.11 & 0.16 & 0.21 & 0.27 & 0.78 & 0.77 & 0.78 & 0.83 \\
USA & 0.14 & 0.11 & 0.15 & 0.24 & 0.68 & 0.64 & 0.67 & 0.76 \\
\hline
\end{tabular}

\begin{tabular}{|c|c|c|c|c|c|c|c|c|c|c|c|c|}
\hline \multirow[b]{2}{*}{ age } & \multicolumn{4}{|c|}{ Completed upper secondary } & \multicolumn{4}{|c|}{ Completed vocational-technical tertiary } & \multicolumn{4}{|c|}{ Completed academic tertiary } \\
\hline & $26-35$ & $36-45$ & $46-55$ & $56-65$ & $26-35$ & $36-45$ & $46-55$ & $56-65$ & $26-35$ & $36-45$ & $46-55$ & $56-65$ \\
\hline Belgium & 0.30 & 0.42 & 0.53 & 0.69 & 0.67 & 0.73 & 0.78 & 0.87 & 0.86 & 0.89 & 0.90 & 0.94 \\
\hline Denmark & 0.15 & 0.20 & 0.22 & 0.33 & 0.73 & 0.73 & 0.73 & 0.81 & 0.93 & 0.95 & 0.95 & 0.97 \\
\hline Finland & 0.15 & 0.20 & 0.36 & 0.50 & 0.63 & 0.66 & 0.72 & 0.81 & 0.85 & 0.85 & 0.87 & 0.915 \\
\hline Great Britain & 0.14 & 0.20 & 0.28 & 0.41 & 0.77 & 0.76 & 0.79 & 0.84 & 0.85 & 0.85 & 0.88 & 0.92 \\
\hline New Zealand & 0.36 & 0.36 & 0.45 & 0.53 & 0.76 & 0.72 & 0.74 & 0.79 & 0.86 & 0.87 & 0.90 & 0.94 \\
\hline Switzerland $^{* *}$ & 0.12 & 0.17 & 0.20 & 0.29 & 0.75 & 0.75 & 0.78 & 0.82 & 0.84 & 0.85 & 0.87 & 0.89 \\
\hline
\end{tabular}

*: French and German speaking Switzerland

${ }^{* *}$ : Italian speaking Switzerland

Source: Author calculations from Organization for Economic Co-operation and Development (2005). 
cohorts: 26-35, 36-45, 46-55, and 56-65. We control for gender, selectivity of schooling, age, and age squared. Since we control for selectivity (i.e., aggregate ability differences) and the aging process, the coefficient estimate on a cohort specific schooling measure is interpreted as the contribution to cognitive skills of an extra year of education of the cohort. It reflects the quality of the education received by the cohort.

Coefficient estimates on cohort specific years of schooling and selectivity for each country are reported in Table 3. For example, for the cohort aged 26-35 in the US, one more year of schooling increases one's cognitive skill by 0.16 standard deviations. Also reported is the p-value for the F-test that one more year of schooling of each cohort has the same contribution to the cognitive skill. For most countries, schooling's contribution to cognitive skills has increased gradually over time; the increase from the cohort aged 56-65 to the cohort aged 26-35 ranges from $13 \%$ in Poland to $100 \%$ in Germany, and the trend is statistically significant. For Switzerland, United States and Italy, there is barely any change in the point estimates for schooling's contribution over time, and the differences across cohorts are not statistically significant at the 5 percent level. The coefficient estimates for Chile decrease over time, but it is not statistically significant at conventional levels.

Selectivity is also important in tracking cognitive skills across cohorts. Our measure of selectivity of different school attainment has a positive effect on cognitive skills for all countries but Italy and is statistically significant at the 5 percent level for all but Chile and the Czech Republic. The coefficient estimates on cohort specific years of schooling suggest that education quality has increased steadily over time for most of the European countries. A plausible, albeit speculative, explanation for this pattern of change 
Table 3. Contribution of School Attainment and Selectivity to Literacy Scores by Ten-year Age Cohorts

\begin{tabular}{|c|c|c|c|c|c|c|c|c|c|c|c|c|c|}
\hline Age cohort & Chile & $\begin{array}{c}\text { Czech } \\
\text { Republic }\end{array}$ & Denmark & Finland & Germany & Hungary & Italy & Netherlands & Norway & Poland & Sweden & Switzerland & USA \\
\hline \multirow[t]{2}{*}{$26-35$} & 0.155 & 0.181 & 0.146 & 0.121 & 0.072 & 0.127 & 0.171 & 0.078 & 0.143 & 0.157 & 0.095 & 0.124 & 0.161 \\
\hline & {$[0.008]^{* *}$} & {$[0.015]^{* *}$} & {$[0.009]^{* *}$} & {$[0.007]^{* *}$} & {$[0.011]^{* *}$} & {$[0.011]^{* *}$} & {$[0.012]^{* *}$} & {$[0.008]^{* *}$} & {$[0.012]^{* *}$} & {$[0.010]^{* *}$} & {$[0.009]^{* *}$} & {$[0.010]^{* *}$} & {$[0.010]^{* *}$} \\
\hline \multirow[t]{2}{*}{$36-45$} & 0.151 & 0.162 & 0.142 & 0.107 & 0.061 & 0.114 & 0.165 & 0.068 & 0.141 & 0.154 & 0.075 & 0.114 & 0.165 \\
\hline & {$[0.007]^{* *}$} & {$[0.014]^{* *}$} & {$[0.009]^{* *}$} & {$[0.007]^{* *}$} & {$[0.012]^{* *}$} & {$[0.011]^{* *}$} & {$[0.012]^{* *}$} & {$[0.008]^{* *}$} & {$[0.012]^{* *}$} & {$[0.009]^{* *}$} & {$[0.009]^{* *}$} & {$[0.011]^{* *}$} & {$[0.010]^{* *}$} \\
\hline \multirow[t]{2}{*}{$46-55$} & 0.161 & 0.16 & 0.129 & 0.099 & 0.058 & 0.1 & 0.172 & 0.056 & 0.132 & 0.144 & 0.081 & 0.117 & 0.163 \\
\hline & {$[0.008]^{* *}$} & {$[0.014]^{* *}$} & {$[0.009]^{* *}$} & {$[0.008]^{* *}$} & {$[0.013]^{* *}$} & {$[0.011]^{* *}$} & {$[0.013]^{* *}$} & {$[0.008]^{* *}$} & {$[0.013]^{* *}$} & {$[0.010]^{* *}$} & {$[0.009]^{* *}$} & {$[0.011]^{* *}$} & {$[0.010]^{* *}$} \\
\hline \multirow[t]{2}{*}{$56-65$} & 0.169 & 0.156 & 0.124 & 0.077 & 0.036 & 0.087 & 0.164 & 0.049 & 0.111 & 0.139 & 0.069 & 0.117 & 0.162 \\
\hline & {$[0.009]^{* *}$} & {$[0.015]^{* *}$} & {$[0.010]^{* *}$} & {$[0.009]^{* *}$} & {$[0.015]^{*}$} & {$[0.013]^{* *}$} & {$[0.014]^{* *}$} & {$[0.009]^{* *}$} & {$[0.014]^{* *}$} & {$[0.011]^{* *}$} & {$[0.010]^{* *}$} & {$[0.012]^{* *}$} & {$[0.012]^{* *}$} \\
\hline $\mathrm{p}$-value & 0.11 & 0 & 0 & 0 & 0 & 0 & 0.17 & 0 & 0 & 0.05 & 0 & 0.17 & 0.79 \\
\hline \multirow[t]{2}{*}{ Selectivity } & 0.048 & 0.077 & 0.311 & 0.641 & 0.617 & 0.431 & -0.292 & 0.887 & 0.356 & 0.207 & 0.530 & 0.196 & 0.170 \\
\hline & {$[0.083]$} & {$[0.104]$} & {$[0.068]^{* *}$} & {$[0.078]^{* *}$} & {$[0.127]^{* *}$} & {$[0.113]^{* *}$} & {$[0.125]^{*}$} & {$[0.079]^{* *}$} & {$[0.112]^{* *}$} & {$[0.082]^{*}$} & {$[0.085]^{* *}$} & {$[0.086]^{*}$} & {$[0.103]^{+}$} \\
\hline
\end{tabular}

[Robust standard errors in brackets]

${ }^{+}$significant at $10 \% ;{ }^{*}$ significant at $5 \% ;{ }^{* *}$ significant at $1 \%$

Notes: Sample includes all individuals between 26 and 65 years of age. Dependent variable is the normalized average literacy skill test score. Control variables are age, age squared, country-specific school selectivity, and a country-specific indicator for female. Education's contributions to literacy skills for different cohorts are the coefficient estimates on the interactive terms between education (measure by total years of schooling) and indicators for the respective age cohorts. P-value is for the F-test that education's contributions to literacy skill are the same over the four cohorts. 
in school quality relates to World War II and its aftermath. Countries experiencing significant quality improvement tend to be those deeply involved in World War II; their education system experienced severe damage and disruption during the war and had to be reconstructed in the post-war period. The oldest cohort, who received their education during or immediately after the war, would have suffered the most. With the national education system gradually back to normal, the quality of education increased for the following cohorts. The education systems in the U.S,, Chile, Switzerland, and Italy were relatively undisrupted during the war, perhaps supporting the stable quality of schooling over this period. ${ }^{17}$

The coefficients on age and age squared (common to all countries) are 0.019 and -0.00028 respectively; they are jointly significantly different from zero. By these estimates, cognitive skills increase slightly with age for individuals between 26 and 34 years of age and then start to decay with rapid drop off after 55 years of age. This pattern is consistent with findings in the literature on psychology of adult learning (see Smith and Marsiske (1997) and references therein).

One concern is that the quality of primary-secondary schooling and the quality of college education evolve differently. We address this concern by splitting years of schooling into two parts: years of primary-secondary schooling ( $\mathrm{S} \leq 12$ years) and years of tertiary education $(\mathrm{S}>12$ years). Appendix Table A1 reports the coefficient estimates on cohort specific primary-secondary schooling and tertiary schooling for each country, again providing estimates of the contribution of one extra year of primary-secondary schooling or college education to the cognitive skills for different cohorts. For every

\footnotetext{
${ }^{17}$ See Lowe (1992) and U.S. Office of Education (1945). While Italy was clearly a combatant, Italy's wartime experience apparently had minimal effect on the schools, and the postwar reconstruction proceeded rapidly; see Wolff (1992).
} 
cohort in every country, primary-secondary schooling has a much bigger contribution to cognitive skills than college education. This is expected given that the skills tested by IALS are day-to-day tasks and are more directly affected by basic education. For the same reason, the trends observed in Table 3 reflect to a large extent the evolution of the primary-secondary schooling quality, as displayed in Appendix Table A1. The estimated changes in quality of tertiary schooling are generally insignificant, although this could simply reflect the much smaller samples of tertiary graduates than of primary and secondary schooling.

Taking the cohort aged 26-35 as the base cohort, we construct a quality-adjusted measure of years of schooling as defined in Equation (2), using the cohort-specific estimate of education's contribution to literacy skills reported in Table 3. Our qualityadjusted schooling measure is used to determine the lifetime return to different levels of schooling for the base cohort. ${ }^{18}$

\section{Returns to Skills in the Labor Market}

We now turn to the estimation of quality-consistent returns to schooling and returns to literacy skills in the labor market. We apply a standard Mincer framework using the quality-adjusted years of schooling measure as in Equation (3):

$$
\ln \left(y_{i k c}\right)=\delta_{1 k} \cdot \tilde{S}_{i k c}+\delta_{2 k} \cdot L_{i k}+Z_{i k} \cdot \theta_{k}+v_{i k c}
$$

\footnotetext{
${ }^{18}$ A quality-adjusted schooling measure constructed from Appendix Table A1 is very similar given the
} closeness of estimates between Tables 3 and A1. 
The dependent variable, $\ln \left(y_{i k c}\right)$, is the logarithm of annual earnings from employment in the survey year of individual $i . \widetilde{S_{i k c}}$ is individual $i$ 's quality-adjusted years of schooling. $L_{i k c}$ is individual $i$ 's normalized literacy skills test score. The literacy skill measure is intended to proxy for individual productivity in the work place that is not captured by adjusted schooling. $Z_{i k}$ is a vector of control variable, including an indicator for female, potential experience, and an indicator for living in the rural area, and $\theta_{k}$ is the vector of relevant parameters. Because schooling is normalized relative to the quality of the youngest cohort's schooling, the coefficient estimate of $\delta_{1 k}$ measures the lifetime return to schooling for the youngest cohort in country $k$. The return to measured cognitive skills is $\delta_{2 k}$.

While Equation (3) is our preferred earnings model, we provide separate estimates of models with and without quality adjustments to schooling and with and without inclusion of cognitive skills. In this way, we can relate our estimates to the common alternatives in the literature.

In the earnings analysis, we focus on the 13 countries with continuous wage measures in IALS. ${ }^{19}$ We estimate the returns to education and to literacy skills using the sample of individuals working fulltime during the 12 months prior to the survey. Fulltime workers are defined as those working at least 40 weeks and at least 30 hours per week

\footnotetext{
${ }^{19}$ Three countries (regions) with continuous wage measures are not included in the wage analysis for different reasons. Canada does not have an age measure; Slovenia does not have historical information on schooling patterns for estimation of the selectivity measure; and Italian speaking Switzerland has too few observations.
} 
during the previous 12 months. ${ }^{20}$ Whenever we include quality-adjusted schooling, we rely upon the estimates from the full IALS sample that were reported in Table 3.

\subsection{Adjustment for School Quality}

As a benchmark, we first estimate a classical Mincer wage equation using actual years of schooling as the measure of the quantity of human capital, controlling for gender, potential experience and its square, and an indicator for living in a rural area. The return to schooling for each country is reported under Model 1 in Table 4. One extra year of education increases annual earning by from 3.3\% in Sweden to $10.5 \%$ in the United States with an unweighted average across all countries of 6.0 percent. Educational attainment is considerably more highly rewarded in the US than in other developed countries, consistent with findings in the literature. Also noticeable is that the return to education in the four less developed countries (Poland, Czech Republic, Hungary and Chile) is much higher than that in other more developed European countries.

The classical Mincer framework makes use of variation in years of schooling received at different time periods, and, as demonstrated, the quality of the schooling is not comparable over time, making the Mincer estimates an average of the returns to education of different qualities. The second panel of Table 4 reports the estimated return to quality-adjusted schooling for the base cohort, the cohort aged 26-35 in the survey year for each country.

While adjusting for secular changes in school quality makes little to no difference in Chile, Italy, and the U.S., it substantially alters the estimated returns to schooling in the remaining countries. The most salient difference between Model 1 and Model 2 in Table

\footnotetext{
${ }^{20}$ For Sweden, the fulltime working status is based on answers to questions of whether a respondent works and whether he works fulltime.
} 
Table 4. Alternative Estimates of the Returns to Schooling and Literacy Skills in the Labor Market

\begin{tabular}{|c|c|c|c|c|c|c|c|c|c|c|c|c|c|}
\hline & Chile & $\begin{array}{c}\text { Czech } \\
\text { Republic }\end{array}$ & Denmark & Finland & Germany & Hungary & Italy & Netherlands & Norway & Poland & Sweden & Switzerland & USA \\
\hline \multicolumn{14}{|l|}{ Model 1} \\
\hline Schooling & $\begin{array}{c}0.102 \\
{[0.009]^{* *}}\end{array}$ & $\begin{array}{c}0.062 \\
{[0.007]^{* *}}\end{array}$ & $\begin{array}{c}0.048 \\
{[0.004]^{* *}}\end{array}$ & $\begin{array}{c}0.045 \\
{[0.006]^{* *}}\end{array}$ & $\begin{array}{c}0.044 \\
{[0.009]^{* *}}\end{array}$ & $\begin{array}{c}0.076 \\
{[0.009]^{* *}}\end{array}$ & $\begin{array}{c}0.056 \\
{[0.005]^{* *}}\end{array}$ & $\begin{array}{c}0.043 \\
{[0.004]^{* *}}\end{array}$ & $\begin{array}{c}0.042 \\
{[0.005]^{* *}}\end{array}$ & $\begin{array}{c}0.081 \\
{[0.009]^{* *}}\end{array}$ & $\begin{array}{c}0.033 \\
{[0.005]^{* *}}\end{array}$ & $\begin{array}{c}0.042 \\
{[0.005]^{* *}}\end{array}$ & $\begin{array}{c}0.105 \\
{[0.008]^{* *}}\end{array}$ \\
\hline \multicolumn{14}{|l|}{ Model 2} \\
\hline $\begin{array}{l}\text { Quality-adj. } \\
\text { schooling }\end{array}$ & $\begin{array}{c}0.098 \\
{[0.009]^{* *}}\end{array}$ & $\begin{array}{c}0.072 \\
{[0.008]^{* *}}\end{array}$ & $\begin{array}{c}0.055 \\
{[0.005]^{* *}}\end{array}$ & $\begin{array}{c}0.056 \\
{[0.008]^{* *}}\end{array}$ & $\begin{array}{c}0.056 \\
{[0.012]^{* *}}\end{array}$ & $\begin{array}{c}0.096 \\
{[0.012]^{* *}}\end{array}$ & $\begin{array}{c}0.058 \\
{[0.005]^{* *}}\end{array}$ & $\begin{array}{c}0.057 \\
{[0.006]^{* *}}\end{array}$ & $\begin{array}{c}0.048 \\
{[0.006]^{* *}}\end{array}$ & $\begin{array}{c}0.089 \\
{[0.010]^{* *}}\end{array}$ & $\begin{array}{c}0.04 \\
{[0.006]^{* *}}\end{array}$ & $\begin{array}{c}0.046 \\
{[0.005]^{* *}}\end{array}$ & $\begin{array}{c}0.104 \\
{[0.008]^{* *}}\end{array}$ \\
\hline \multicolumn{14}{|l|}{ Model 3} \\
\hline $\begin{array}{l}\text { Quality-adj. } \\
\text { schooling }\end{array}$ & $\begin{array}{c}0.076 \\
{[0.010]^{* *}}\end{array}$ & $\begin{array}{c}0.063 \\
{[0.009]^{* *}}\end{array}$ & $\begin{array}{c}0.046 \\
{[0.006]^{* *}}\end{array}$ & $\begin{array}{c}0.043 \\
{[0.008]^{* *}}\end{array}$ & $\begin{array}{c}0.048 \\
{[0.012]^{* *}}\end{array}$ & $\begin{array}{c}0.086 \\
{[0.014]^{* *}}\end{array}$ & $\begin{array}{c}0.053 \\
{[0.005]^{* *}}\end{array}$ & $\begin{array}{c}0.04 \\
{[0.006]^{* *}}\end{array}$ & $\begin{array}{c}0.038 \\
{[0.006]^{* *}}\end{array}$ & $\begin{array}{c}0.088 \\
{[0.010]^{* *}}\end{array}$ & $\begin{array}{c}0.033 \\
{[0.006]^{* *}}\end{array}$ & $\begin{array}{c}0.03 \\
{[0.006]^{* *}}\end{array}$ & $\begin{array}{c}0.064 \\
{[0.009]^{* *}}\end{array}$ \\
\hline Literacy & $\begin{array}{c}0.151 \\
{[0.035]^{* *}}\end{array}$ & $\begin{array}{c}0.051 \\
{[0.018]^{* *}}\end{array}$ & $\begin{array}{c}0.065 \\
{[0.014]^{* *}}\end{array}$ & $\begin{array}{c}0.107 \\
{[0.025]^{* *}}\end{array}$ & $\begin{array}{c}0.08 \\
{[0.021]^{* *}}\end{array}$ & $\begin{array}{c}0.071 \\
{[0.036]^{+}} \\
\end{array}$ & $\begin{array}{c}0.045 \\
{[0.020]^{*}} \\
\end{array}$ & $\begin{array}{c}0.154 \\
{[0.019]^{* *}}\end{array}$ & $\begin{array}{c}0.071 \\
{[0.019]^{* *}}\end{array}$ & $\begin{array}{c}0.008 \\
{[0.025]}\end{array}$ & $\begin{array}{c}0.066 \\
{[0.018]^{* *}}\end{array}$ & $\begin{array}{c}0.118 \\
{[0.020]^{* *}}\end{array}$ & $\begin{array}{c}0.241 \\
{[0.029]^{* *}}\end{array}$ \\
\hline \multicolumn{14}{|l|}{ Model 4} \\
\hline Schooling & $\begin{array}{c}0.079 \\
{[0.010]^{* *}}\end{array}$ & $\begin{array}{c}0.054 \\
{[0.008]^{* *}}\end{array}$ & $\begin{array}{c}0.04 \\
{[0.005]^{* *}}\end{array}$ & $\begin{array}{c}0.036 \\
{[0.006]^{* *}}\end{array}$ & $\begin{array}{c}0.038 \\
{[0.009]^{* *}}\end{array}$ & $\begin{array}{c}0.069 \\
{[0.010]^{* *}}\end{array}$ & $\begin{array}{c}0.051 \\
{[0.005]^{* *}}\end{array}$ & $\begin{array}{c}0.032 \\
{[0.004]^{* *}}\end{array}$ & $\begin{array}{c}0.033 \\
{[0.005]^{* *}}\end{array}$ & $\begin{array}{c}0.08 \\
{[0.010]^{* *}}\end{array}$ & $\begin{array}{c}0.028 \\
{[0.005]^{* *}}\end{array}$ & $\begin{array}{c}0.028 \\
{[0.005]^{* *}}\end{array}$ & $\begin{array}{c}0.065 \\
{[0.009]^{* *}}\end{array}$ \\
\hline Literacy & $\begin{array}{c}0.15 \\
{[0.035]^{* *}}\end{array}$ & $\begin{array}{c}0.05 \\
{[0.018]^{* *}}\end{array}$ & $\begin{array}{c}0.064 \\
{[0.014]^{* *}}\end{array}$ & $\begin{array}{c}0.103 \\
{[0.024]^{* *}}\end{array}$ & $\begin{array}{c}0.078 \\
{[0.020]^{* *}}\end{array}$ & $\begin{array}{c}0.065 \\
{[0.036]^{+}} \\
\end{array}$ & $\begin{array}{c}0.046 \\
{[0.020]^{*}}\end{array}$ & $\begin{array}{c}0.148 \\
{[0.019]^{* *}}\end{array}$ & $\begin{array}{c}0.072 \\
{[0.019]^{* *}}\end{array}$ & $\begin{array}{c}0.008 \\
{[0.025]}\end{array}$ & $\begin{array}{c}0.064 \\
{[0.017]^{* *}}\end{array}$ & $\begin{array}{c}0.118 \\
{[0.020]^{* *}}\end{array}$ & $\begin{array}{c}0.241 \\
{[0.029]^{* *}}\end{array}$ \\
\hline Observations & 1183 & 1259 & 1525 & 1262 & 594 & 761 & 892 & 1105 & 1454 & 1062 & 1207 & 1034 & 1196 \\
\hline
\end{tabular}

[Robust standard errors in brackets]

${ }^{+}$significant at $10 \% ;{ }^{*}$ significant at $5 \% ;{ }^{* *}$ significant at $1 \%$

Sample includes full-time workers between 26 and 65 years of age. In all the models, the dependent variable is the logarithm of annual earnings from employment; control variables are gender, potential experience and its square, and an indicator for living in rural area. In Model 1 education is measured by actual years of schooling. In Model 2, education is measured by quality-adjusted years of schooling, where the quality index of schooling is derived from education's contribution literacy skills. Model 3 is Model 2 controlling for individual literacy skill. Model 4 is Model 1 controlling for individual literacy skill. 
4 is that there is a significant increase in the return to education for most countries. The increase in returns is over 30 percent in the Netherlands, and five of the 13 countries show an increase in excess of 20 percent of the standard Mincer estimates. Table 6 displays the change in the rates of return estimates that comes from accounting for quality movements, with an average of 15 percent increase from the basic Mincer return.

Estimates of Model 2 have smaller variation than those of Model 1. In particular, the gap in the return to education between the United States and other countries becomes smaller once the change in education quality is taken into account. This is readily seen in Figure 2 that plots the unadjusted and adjusted Mincer returns across the 13 countries. This convergence of estimates suggests that the much higher reward to education in the US relative to other countries is in part an artifact of the stable quality of its education system. With large improvement in the education system of other countries, the gap in the return to education is noticeably smaller for today's graduates.

\subsection{Adjustment for Cognitive Skills}

Measures of cognitive skills in Mincer earnings functions serve two purposes.

First, when the focus is school attainment, introduction of cognitive skills is viewed as a direct way to correct for ability bias in estimating rates of return (see Card (1999)).

Second, cognitive skills permit investigation of how the labor market values different skills, including those that might be related to schools and other policy levers. To investigate how literacy skills are rewarded in the labor market of each country, we add the normalized literacy score to the wage equation in Model 2. As shown in the third panel with Model 3, literacy skills have a positive and statistically significant effect on earnings in all countries except Poland. 


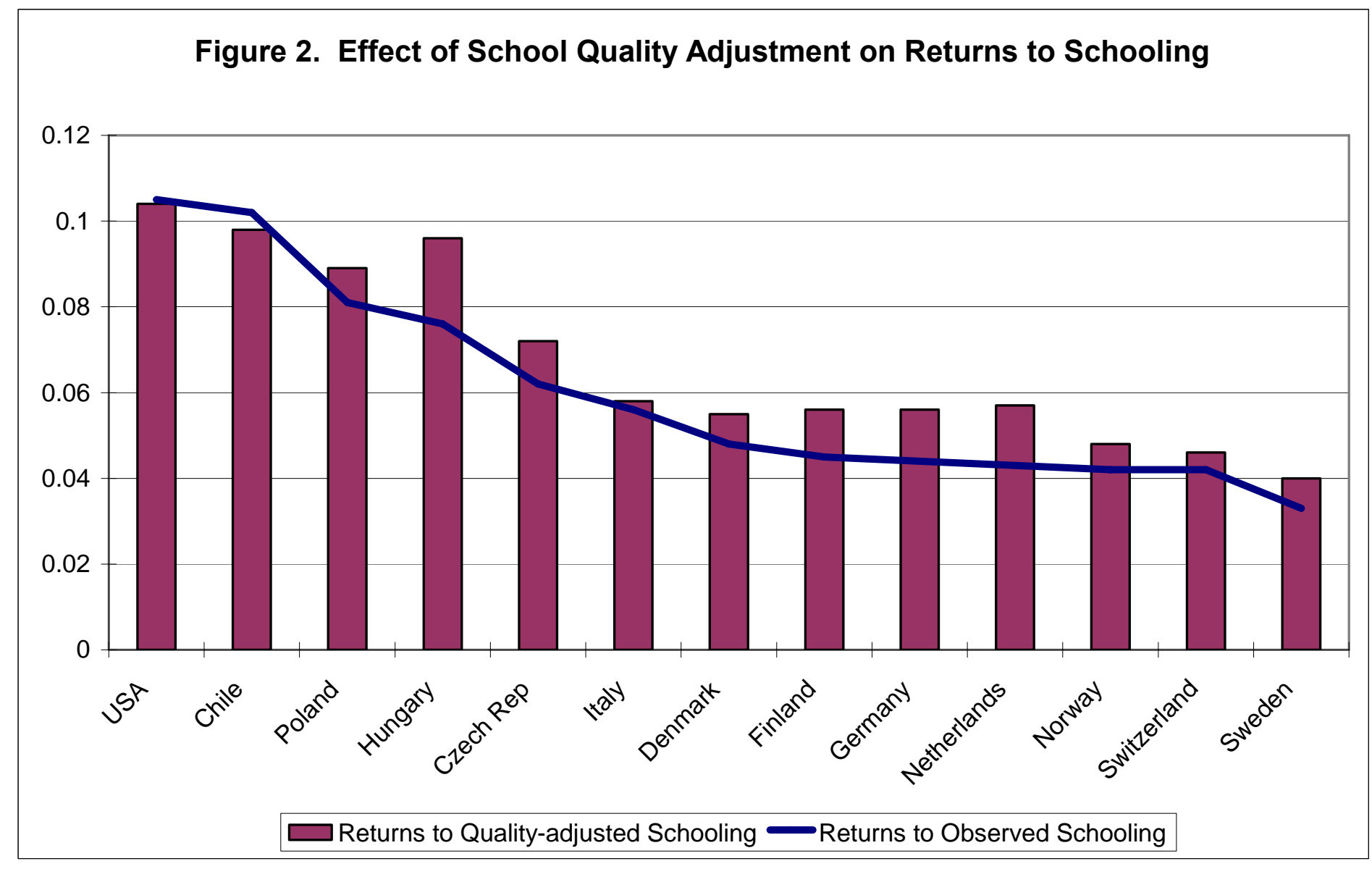


After controlling for cognitive skills, the estimated return to education drops in all countries. Thus, a considerable part of the estimated return to education in the classical Mincer framework appears due to classical ability bias from the more able also getting more schooling. The return to school attainment, however, is still positive and significant, suggesting that schooling itself captures different individual characteristics than literacy skills.

The pattern of returns along with the impact of ability bias on the estimates is illustrated in Figure 3. Our preferred estimates that adjust both for school quality and for individual cognitive skills are shown as the solid line. The bars represent the qualityadjusted returns to schooling without consideration of individual literacy scores. Compared with Figure 2, it is clear that the two biases from standard estimation that ignores both school quality and individual cognitive skills tend to offset within these data: The larger returns from quality adjustment are reduced by considering ability bias. Moreover, adjusting for individual ability lowers the U.S. return to quality adjusted school attainment so that it is no longer the highest of our sampled countries.

With the exception of the United States, the high returns to schooling are systematically found in the less developed countries in our sample. The countries with more developed welfare states fall in the lower range of returns, but this is not just because of higher taxes because these results are all pretax earnings.

The impact of cognitive skills is itself important. One standard deviation increase in the literacy score increases annual earnings by from 5 percent in Italy to 24 percent in the United States. The reward to cognitive skills falls between 5 percent and 15 percent for all countries other than the U.S. Figure 4 shows the returns to literacy scores across 


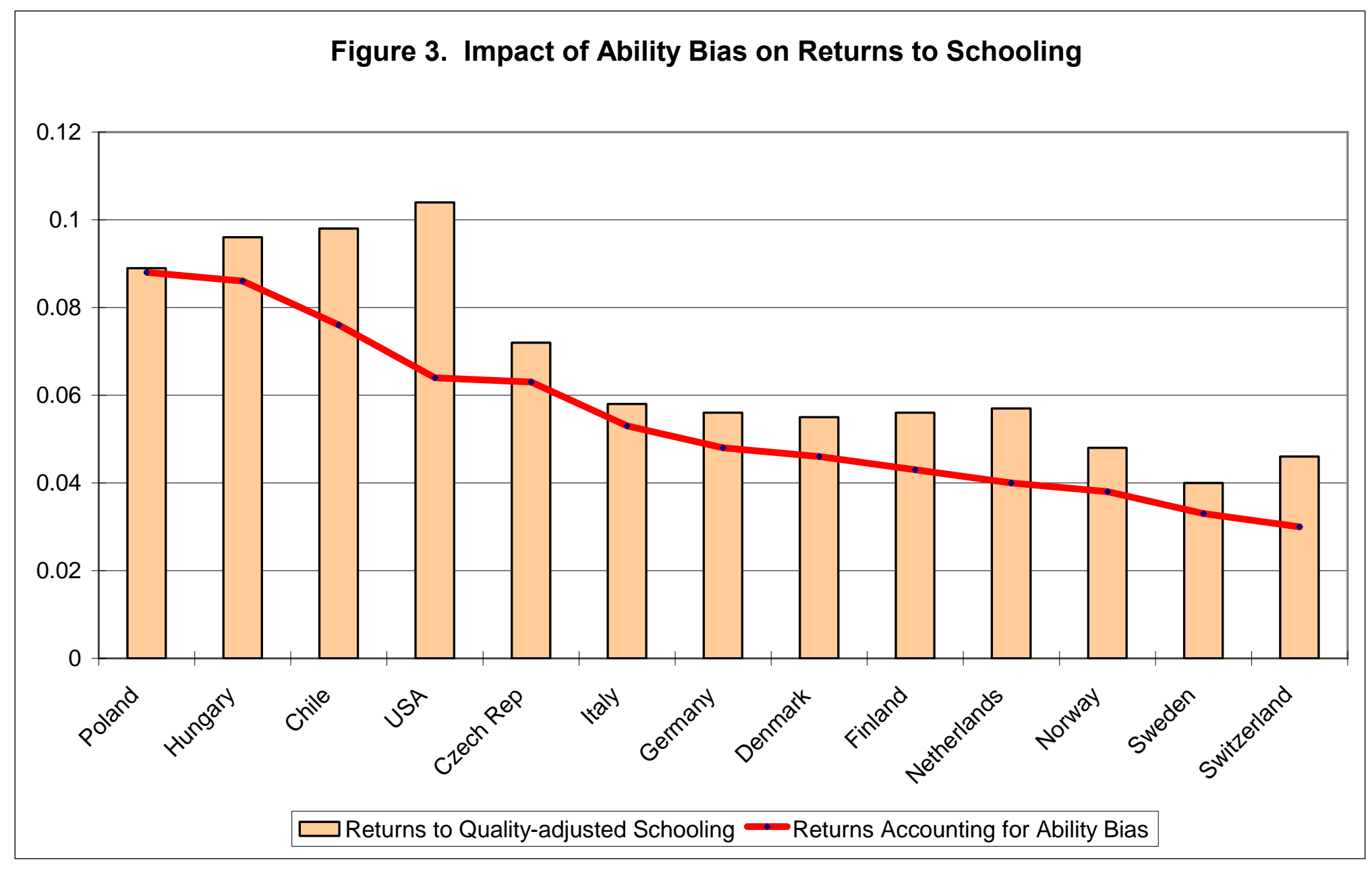




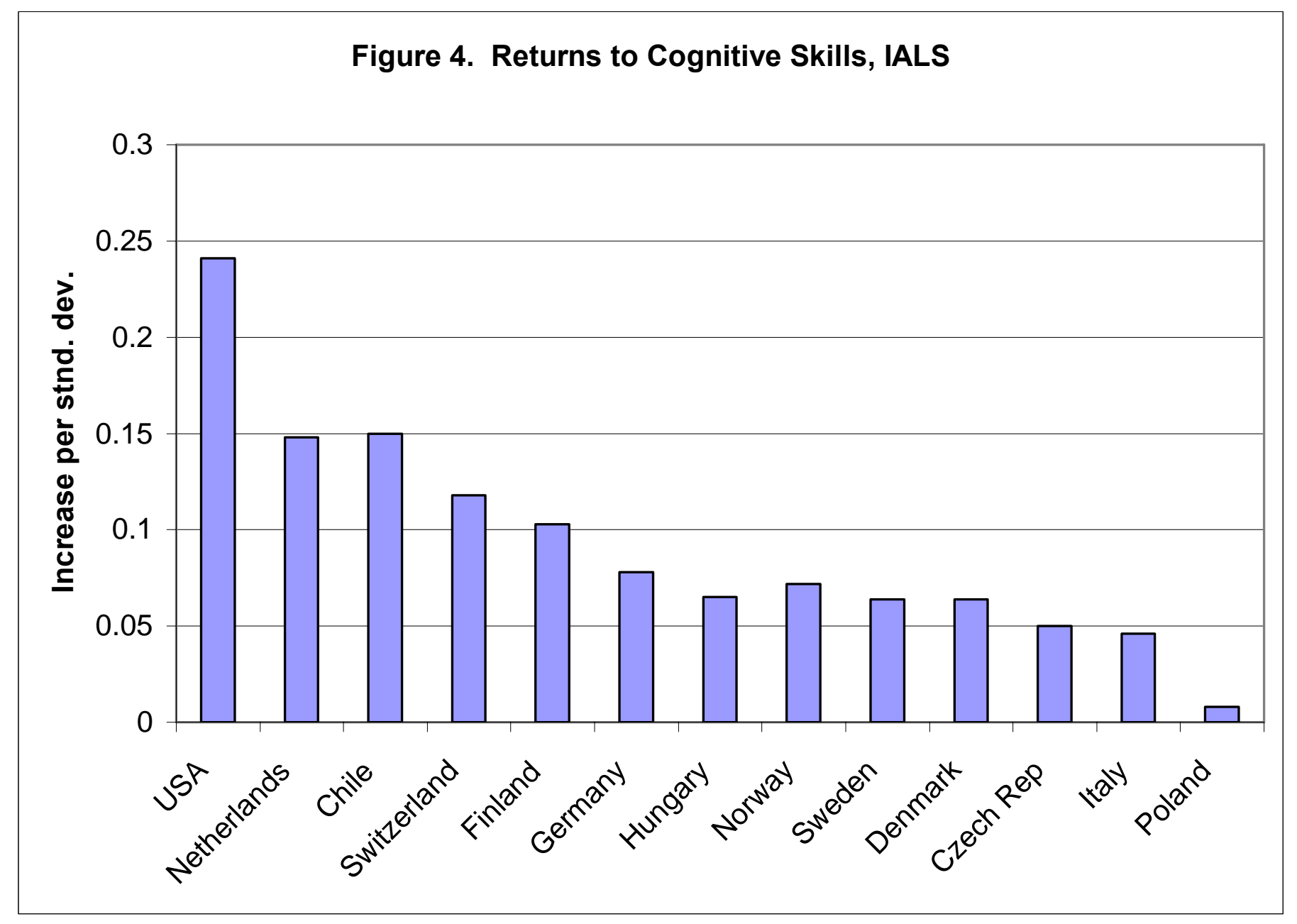


countries. Contrary to the pattern of returns to school attainment in Figure 3, there is no obvious pattern as to where the returns to cognitive skills are high or low.

The estimates of the returns to skill in the IALS data for the United States are significantly above those in recent studies. Using separate panel data on returns to cognitive skills early in a career, three different estimates point very consistently to a return of about 12 percent per standard deviation (see Mulligan (1999); Murnane, Willett, Duhaldeborde, and Tyler (2000); Lazear (2003)). ${ }^{21}$ Our larger estimates may reflect the returns that accrue later in the working life and that are not observed in these panel data estimates.

For a final comparison, we estimate the wage equation using actual years-ofschooling measure along with literacy skills. The results - similar to a number of similar U.S. studies - are reported in the bottom panel of Table 4 as Model 4. Compared to Model 1, the estimated return to education drops significantly; compared to Model 3, the return to education is underestimated in most countries except the US, Switzerland, Italy, and Chile. The return to literacy skills, however, is almost identical to that in Row 3. Thus, using the quality-adjusted schooling measure produces similar return to literacy skills and similar changes in the return to education compared to observed schooling measure.

Table 5 summarizes the impact of the adjustment for school quality in models that do and do not control for literacy scores of the individuals. Comparing the columns of

\footnotetext{
${ }^{21}$ Murnane, Willett, Duhaldeborde, and Tyler (2000) provide evidence from the High School and Beyond and the National Longitudinal Survey of the High School Class of 1972. Their estimates suggest some variation with males obtaining a 15 percent increase and females a 10 percent increase per standard deviation of test performance. Lazear (2003), relying on a somewhat younger sample from NELS88, provides a single estimate of 12 percent. These estimates are also very close to those in Mulligan (1999), who finds 11 percent for the normalized AFQT score in the NLSY data.
} 


\section{Table 5. Impact of School Quality Adjustment on Labor Market Returns With and Without Adjustment for Individual Ability}

\begin{tabular}{l|cc}
\hline country & $\begin{array}{c}\text { \% change with } \\
\text { school quality }^{\text {adjustment }^{\mathrm{a}}}\end{array}$ & $\begin{array}{c}\text { \% change } \\
\text { controlling for } \\
\text { literacy score }^{\mathrm{b}}\end{array}$ \\
\hline Netherlands & 32.6 & 25.0 \\
Germany & 27.3 & 26.3 \\
Hungary & 26.3 & 24.6 \\
Finland & 24.4 & 19.4 \\
Sweden & 21.2 & 17.9 \\
Czech Republic & 16.1 & 16.7 \\
Denmark & 14.6 & 15.0 \\
Norway & 14.3 & 15.2 \\
Poland & 9.9 & 10.0 \\
Switzerland (F, G) & 9.5 & 7.1 \\
Italy & 3.6 & 3.9 \\
USA & -1.0 & -1.5 \\
Chile & -3.9 & -3.8 \\
\hline & & \\
Mean & 15.0 & 13.5 \\
Standard Deviation & 11.2 & 9.8 \\
Min & -3.9 & -3.8 \\
Max & 32.6 & 26.3 \\
\hline
\end{tabular}

Notes:

a. Calculated from Table 4 as (return to quality-adjusted education - return to education)/return to education $* 100$ in Models 1 and 2 wage regression that do not control for literacy score.

b. Calculated from Table 4 as (return to quality-adjusted education - return to education)/return to education $* 100$ in Models 3 and 4 wage regression that control for literacy score. 
Table 5 shows that the changes from introducing quality adjustments to schooling are almost identical whether or not literacy scores are independently added (with a correlation of 0.98 for the 13 countries). Again, while the adjustments are not very important for the U.S., where a majority of the existing earnings analyses have been conducted, the same is not true for other countries in the sample.

It is interesting to compare the returns to schooling and the returns to cognitive skills to the levels of schooling in the different countries. The top panel of Figure 5 shows that the returns to added schooling clearly drop with higher levels of schooling. This pattern follows the frequently hypothesized diminishing returns to schooling. On the other hand, the returns to cognitive skills tend to rise with schooling levels.

\subsection{Test of Statistical Discrimination Hypothesis}

In an intriguing paper, Altonji and Pierret (2001) suggest that the role of cognitive skills - which are difficult for an employer to observe - may grow with the worker's experience in the labor market. At initial hiring, the employer relies more on the observable measures of school attainment, but as time goes on the employer can substitute direct observations of worker skills (measured here by literacy scores) for the cruder proxy of years of schooling. This model is essentially one of statistical discrimination with subsequent learning. We test this statistical discrimination hypothesis across the broader range of countries than Altonji and Pierret had available.

We consider a simple formulation of this model that allows the return to (quality adjusted) schooling and to literacy score to vary between early and late career such as:

$$
\ln \left(y_{i k c}\right)=\delta_{1 k} \cdot \tilde{S}_{i k c}+\delta_{2 k} \cdot L_{i k c}+Z_{i k c} \cdot \theta_{k}+\alpha_{i}+\delta_{1 k}^{*}\left(\alpha_{i} \cdot \tilde{S}_{i k c}\right)+\delta_{2 k}^{*}\left(\alpha_{i} \cdot L_{i k c}\right)+v_{i k c}
$$


Figure 5. Labor Force Education Attainment and Returns to Education and Literacy Score in Wage Regrssion

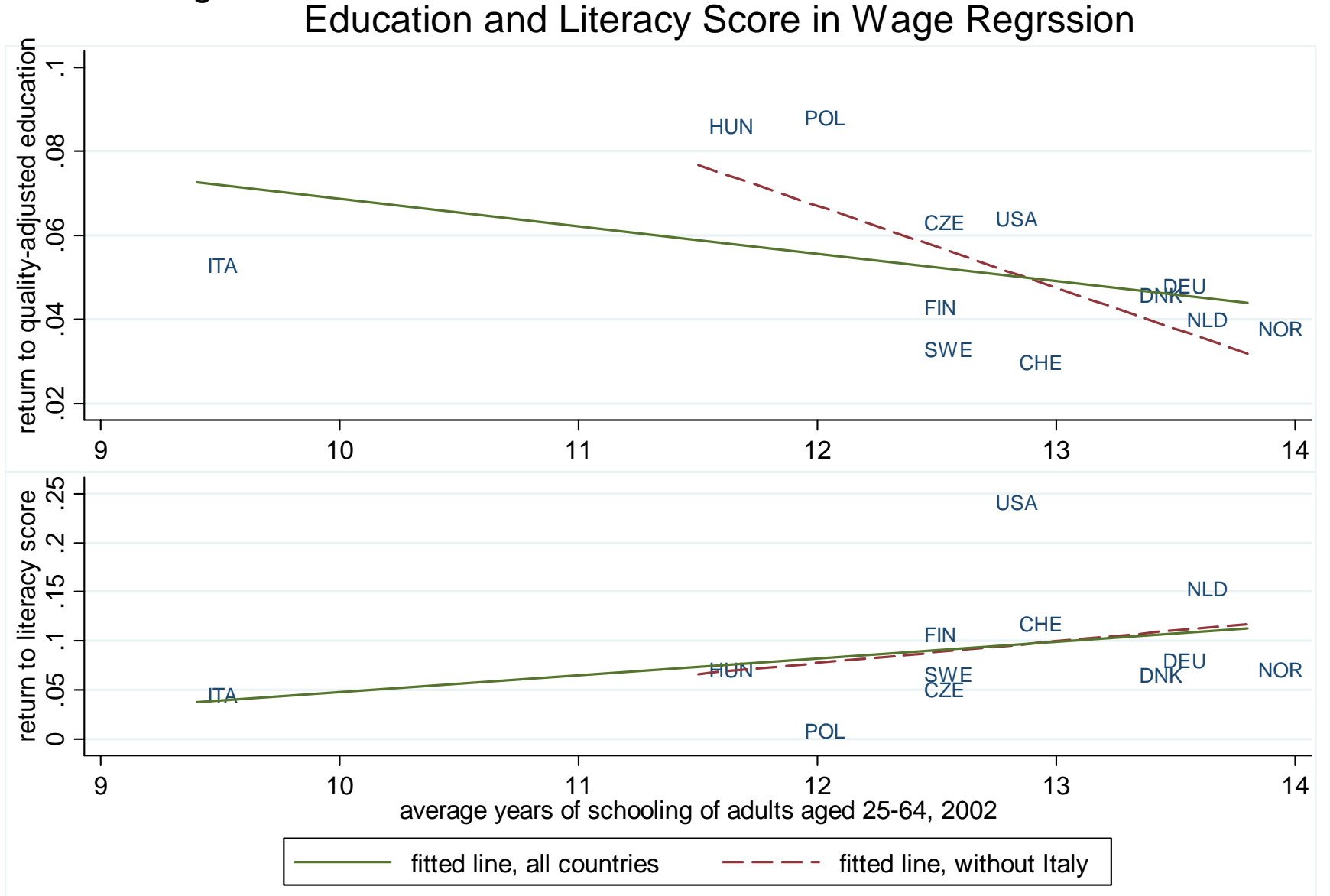


where $\alpha_{i}$ is an indicator for being in the early career stage defined in terms of potential experience. By the statistical discrimination model, $\delta_{1}^{*}$ should be positive (i.e., early returns to schooling exceed later returns) and $\delta_{2}^{*}$ should be negative (i.e., early returns to the difficult to observe cognitive skills are below later returns).

Table 6 provides evidence on this model for the 13 countries with IALS data. The sample includes full-time workers between 16 and 65 years of age. To derive a qualityadjusted years of schooling measure for the cohort between ages 16 and 25, we create a selectivity measure for this cohort from a linear extrapolation of the selectivity measures of cohorts between ages 26 and 36 and between ages 36 and 45 . For these estimates, we define early career as potential experience less than or equal to five years. If we look first at the United States, we see confirmation of the Altonji- Pierret model as changes in compensation from early to later career match the statistical discrimination model. There is, however, little support for this model in other countries. Only Chile produces statistically significant estimates that match the hypothesis. While 10 of the 13 countries have the returns to schooling higher in early career, the estimates are statistically significant in just five (and even significant with the wrong sign in the case of Hungary). Moreover, just half of the countries have even the expected sign on early career returns to literary scores, and only four are statistically significant at the 10 percent level.

We also experimented with different forms of the estimation. Defining the early career cutoff $\left(\alpha_{i}\right)$ at 10 or 15 years yielded no qualitative change. We also applied various interactions between potential experience and both school and literacy scores. These were quite unstable, perhaps reflecting the small samples, but the interactions with 
Table 6. Return to Quality-Adjusted Education at Different Stages of Career, Ages 16-65

\begin{tabular}{|c|c|c|c|c|c|c|c|c|c|c|c|c|c|}
\hline & Chile & $\begin{array}{c}\text { Czech } \\
\text { Republic }\end{array}$ & Denmark & Finland & Germany & Hungary & Italy & Netherlands & Norway & Poland & Sweden & Switzerland & USA \\
\hline Educ, Q-A & $\begin{array}{c}0.081 \\
{[0.011]^{* *}}\end{array}$ & $\begin{array}{c}0.062 \\
{[0.009]^{* *}}\end{array}$ & $\begin{array}{c}0.046 \\
{[0.006]^{* *}}\end{array}$ & $\begin{array}{c}0.042 \\
{[0.008]^{* *}}\end{array}$ & $\begin{array}{c}0.043 \\
{[0.011]^{* *}}\end{array}$ & $\begin{array}{c}0.092 \\
{[0.012]^{* *}}\end{array}$ & $\begin{array}{c}0.047 \\
{[0.007]^{* *}}\end{array}$ & $\begin{array}{c}0.044 \\
{[0.006]^{* *}}\end{array}$ & $\begin{array}{c}0.042 \\
{[0.006]^{* *}}\end{array}$ & $\begin{array}{c}0.084 \\
{[0.010]^{* *}}\end{array}$ & $\begin{array}{c}0.04 \\
{[0.007]^{* *}}\end{array}$ & $\begin{array}{c}0.036 \\
{[0.005]^{* *}}\end{array}$ & $\begin{array}{c}0.063 \\
{[0.008]^{* *}}\end{array}$ \\
\hline $\begin{array}{l}\text { Literacy } \\
1(\text { expe } \leq 5)^{*}\end{array}$ & $\begin{array}{c}0.152 \\
{[0.034]^{* *}}\end{array}$ & $\begin{array}{c}0.049 \\
{[0.017]^{* *}}\end{array}$ & $\begin{array}{c}0.067 \\
{[0.015]^{* *}}\end{array}$ & $\begin{array}{c}0.117 \\
{[0.024]^{* *}}\end{array}$ & $\begin{array}{c}0.081 \\
{[0.020]^{* *}}\end{array}$ & $\begin{array}{c}0.076 \\
{[0.035]^{*}}\end{array}$ & $\begin{array}{c}0.056 \\
{[0.022]^{*}}\end{array}$ & $\begin{array}{c}0.162 \\
{[0.020]^{* *}}\end{array}$ & $\begin{array}{c}0.073 \\
{[0.019]^{* *}}\end{array}$ & $\begin{array}{c}0.011 \\
{[0.025]}\end{array}$ & $\begin{array}{c}0.062 \\
{[0.018]^{* *}}\end{array}$ & $\begin{array}{c}0.119 \\
{[0.020]^{* *}}\end{array}$ & $\begin{array}{c}0.243 \\
{[0.029]^{* *}}\end{array}$ \\
\hline $1(\text { expe } \leq 5)^{*}$ & $\begin{array}{c}0.076 \\
{[0.031]^{*}}\end{array}$ & $\begin{array}{c}-0.01 \\
{[0.038]}\end{array}$ & $\begin{array}{c}0.053 \\
{[0.024]^{*}}\end{array}$ & $\begin{array}{c}0.024 \\
{[0.036]}\end{array}$ & $\begin{array}{c}0.054 \\
{[0.023]^{*}}\end{array}$ & $\begin{array}{c}-0.085 \\
{[0.033]^{*}}\end{array}$ & $\begin{array}{c}0.001 \\
{[0.030]}\end{array}$ & $\begin{array}{c}0.041 \\
{[0.018]^{*}}\end{array}$ & $\begin{array}{c}0.021 \\
{[0.046]}\end{array}$ & $\begin{array}{c}-0.022 \\
{[0.075]}\end{array}$ & $\begin{array}{c}0.071 \\
{[0.047]}\end{array}$ & $\begin{array}{c}0.022 \\
{[0.034]}\end{array}$ & $\begin{array}{c}0.108 \\
{[0.052]^{*}}\end{array}$ \\
\hline Literacy & $\begin{array}{c}-0.354 \\
{[0.117]^{* *}}\end{array}$ & $\begin{array}{c}0.099 \\
{[0.062]}\end{array}$ & $\begin{array}{c}0.014 \\
{[0.060]}\end{array}$ & $\begin{array}{c}-0.336 \\
{[0.096]^{* *}}\end{array}$ & $\begin{array}{c}-0.025 \\
{[0.072]}\end{array}$ & $\begin{array}{c}-0.05 \\
{[0.080]}\end{array}$ & $\begin{array}{c}0.038 \\
{[0.105]}\end{array}$ & $\begin{array}{c}-0.037 \\
{[0.065]}\end{array}$ & $\begin{array}{c}0.012 \\
{[0.132]}\end{array}$ & $\begin{array}{c}0.08 \\
{[0.223]}\end{array}$ & $\begin{array}{c}-0.202 \\
{[0.119]^{+}}\end{array}$ & $\begin{array}{c}0.097 \\
{[0.156]}\end{array}$ & $\begin{array}{c}-0.298 \\
{[0.163]^{+}}\end{array}$ \\
\hline
\end{tabular}

[Robust standard errors in brackets]

${ }^{+}$significant at $10 \% ;{ }^{*}$ significant at $5 \% ;{ }^{* *}$ significant at $1 \%$

Sample includes full-time workers between 16 and 65 years of age. The dependent variable is the logarithm of annual earnings from employment; control variables are gender, potential experience and its square, an indicator for living in rural area, education (measured by quality-adjusted years of schooling), literacy skills, a dummy variable equal to 1 for individuals with potential experience no more than 5 years, and its interaction with education and literacy skills. 
the literacy scores were never statistically significant while the interactions with schooling provided mixed results.

It is plausible that the generally flexible labor markets in the United States use this early career information more efficiently than the less flexible European markets. But, for whatever reason, there is little indication that the general market adjustments of the Altonji-Pierret model are found very broadly outside of the U.S.

\section{Conclusion}

The widespread use of the Mincer earnings model to assess the returns to schooling around the world is testimony to its power to summarize important aspects of human capital investment. It has been broadly used to analyze earnings and income distribution questions both within and across countries. Their interpretation, nevertheless, depends upon the deceptively simple empirical assumption that individuals used in comparisons of schooling and earnings are otherwise similar. This paper not only considers a series of key issues about the "otherwise similar" assumption but also extends the analysis to a larger international context.

Microdata from the International Adult Literacy Survey (IALS) provide a unique opportunity to investigate international differences in the labor market returns to skill. The consistent measures of cognitive skills for workers of different ages within 13 countries permit direct analysis of how selection into schooling at different points in time affects common approaches used in estimating rates of return to schooling.

The concern receiving the most previous attention is that those with more schooling might also be more able, thus leading to an upward bias in the estimated 
returns to schooling. Past work on this, largely based upon U.S. labor markets, has yielded inconsistent evidence about the impact and severity of this potential problem.

Our analysis indicates that this selection bias is very important, leading on average across countries to a 25 percent overestimate of the rate of return to schooling. ${ }^{22}$ The largest upward bias across the sampled countries occurs in the United States, where the unadjusted return exceeds the adjusted return by 60 percent.

A second concern, one that is particularly important in an international context, is that the quality of schooling may have changed over time within a country. If so, treating people with a given level of schooling obtained in different points in time can lead to bias in the estimated returns with the direction depending on the pattern of school quality change.

We construct an education quality index from the contribution of schooling during different periods to cognitive skills (after also correcting for the selectivity of schooling across time for each country). When we estimate wage equations using the quality adjusted schooling measure, we find that the returns to schooling for current cohorts are noticeably higher than the return to the unadjusted education in most countries, with the rate of return underestimated by as much as 30 percent in some countries. But quality adjustments do not affect the United States, and once the quality trends are taken into account, the returns to schooling in other countries appear closer to those in the US.

After applying both corrections to the estimated returns, the naïve Mincer estimates are above the quality-consistent estimates in 8 of our 13 sampled countries.

\footnotetext{
${ }^{22}$ The comparison of impacts of selectivity is unaffected by whether nominal years of schooling or qualityadjusted years of schooling are compared. The impact on estimated returns exceeds 10 percent for all countries except Poland.
} 
The varied results of biases suggest considerable caution in making international comparisons of simple earnings differentials by schooling levels.

Cognitive skills play an important direct role in determining an individual's earnings. Returns to cognitive skills are positive and significant in all but one country. Cognitive skills receive the highest return in the US, and the return to cognitive skills is positively correlated with the level of education attainment across nations.

We also extend the test of statistical discrimination hypothesis (Altonji and Pierret (2001)) to full-time workers between 16 and 65 years of age in the thirteen countries. Under this hypothesis, the returns to easily observable characteristics (such as schooling) fall when employers can more directly view performance, and correspondingly the returns to less easily observed measures (such as cognitive skills) rise. While the estimation confirms these predictions in the United States, there is little support outside the U.S. 


\section{Appendix Table A1. Contribution of School Attainment Less than Tertiary and Tertiary to Literacy Scores by Ten-year Age Cohorts}

\begin{tabular}{|c|c|c|c|c|c|c|c|c|c|c|c|c|c|}
\hline $\begin{array}{l}\text { Age } \\
\text { cohort }\end{array}$ & Chile & $\begin{array}{c}\text { Czech } \\
\text { Republic }\end{array}$ & Denmark & Finland & Germany & Hungary & Italy & $\begin{array}{l}\text { Nether- } \\
\text { lands }\end{array}$ & Norway & oland & Sweden & $\begin{array}{l}\text { Switzer- } \\
\text { land }\end{array}$ & USA \\
\hline \multicolumn{14}{|c|}{ Less than tertiary } \\
\hline $26-35$ & $\begin{array}{c}0.158 \\
{[0.008]^{* *}}\end{array}$ & $\begin{array}{c}0.263 \\
{[0.024]^{* *}}\end{array}$ & $\begin{array}{c}0.221 \\
{[0.016]^{* *}}\end{array}$ & $\begin{array}{c}0.2 \\
{[0.015]^{* *}}\end{array}$ & $\begin{array}{c}0.105 \\
{[0.018]^{* *}}\end{array}$ & $\begin{array}{c}0.164 \\
{[0.017]^{* *}}\end{array}$ & $\begin{array}{c}0.238 \\
{[0.015]^{* *}}\end{array}$ & $\begin{array}{c}0.138 \\
{[0.017]^{* *}}\end{array}$ & $\begin{array}{c}0.233 \\
{[0.017]^{* *}}\end{array}$ & $\begin{array}{c}0.193 \\
{[0.012]^{* *}}\end{array}$ & $\begin{array}{c}0.118 \\
{[0.014]^{* *}}\end{array}$ & $\begin{array}{c}0.228 \\
{[0.019]^{* *}}\end{array}$ & $\begin{array}{c}0.257 \\
{[0.012]^{* *}}\end{array}$ \\
\hline $36-45$ & $\begin{array}{c}0.158 \\
{[0.008]^{* *}}\end{array}$ & $\begin{array}{c}0.239 \\
{[0.024]^{* *}}\end{array}$ & $\begin{array}{c}0.217 \\
{[0.016]^{* *}}\end{array}$ & $\begin{array}{c}0.187 \\
{[0.015]^{* *}}\end{array}$ & $\begin{array}{c}0.091 \\
{[0.019]^{* *}}\end{array}$ & $\begin{array}{c}0.152 \\
{[0.017]^{* *}}\end{array}$ & $\begin{array}{c}0.233 \\
{[0.015]^{* *}}\end{array}$ & $\begin{array}{c}0.128 \\
{[0.017]^{* *}}\end{array}$ & $\begin{array}{c}0.236 \\
{[0.018]^{* *}}\end{array}$ & $\begin{array}{c}0.191 \\
{[0.011]^{* *}}\end{array}$ & $\begin{array}{c}0.105 \\
{[0.014]^{* *}}\end{array}$ & $\begin{array}{c}0.217 \\
{[0.020]^{* *}}\end{array}$ & $\begin{array}{c}0.26 \\
{[0.012]^{* *}}\end{array}$ \\
\hline $46-55$ & $\begin{array}{c}0.176 \\
{[0.009]^{* *}}\end{array}$ & $\begin{array}{c}0.237 \\
{[0.024]^{* *}}\end{array}$ & $\begin{array}{c}0.196 \\
{[0.016]^{* *}}\end{array}$ & $\begin{array}{c}0.176 \\
{[0.016]^{* *}}\end{array}$ & $\begin{array}{c}0.091 \\
{[0.020]^{* *}}\end{array}$ & $\begin{array}{c}0.141 \\
{[0.017]^{* *}}\end{array}$ & $\begin{array}{c}0.239 \\
{[0.016]^{* *}}\end{array}$ & $\begin{array}{c}0.112 \\
{[0.018]^{* *}}\end{array}$ & $\begin{array}{c}0.222 \\
{[0.019]^{* *}}\end{array}$ & $\begin{array}{c}0.183 \\
{[0.012]^{* *}}\end{array}$ & $\begin{array}{c}0.112 \\
{[0.015]^{* *}}\end{array}$ & $\begin{array}{c}0.226 \\
{[0.021]^{* *}}\end{array}$ & $\begin{array}{c}0.269 \\
{[0.012]^{* *}}\end{array}$ \\
\hline $56-65$ & $\begin{array}{c}0.182 \\
{[0.010]^{* *}}\end{array}$ & $\begin{array}{c}0.242 \\
{[0.026]^{* *}}\end{array}$ & $c_{0.186}[0.017]^{* *}$ & $\begin{array}{c}0.154 \\
{[0.018]^{* *}}\end{array}$ & $\begin{array}{c}0.068 \\
{[0.021]^{* *}}\end{array}$ & $\begin{array}{c}0.124 \\
{[0.020]^{* *}}\end{array}$ & $\begin{array}{c}0.234 \\
{[0.018]^{* *}}\end{array}$ & $\begin{array}{c}0.105 \\
{[0.020]^{* *}}\end{array}$ & $\begin{array}{c}0.194 \\
{[0.020]^{* *}}\end{array}$ & $\begin{array}{c}0.171 \\
{[0.014]^{* *}}\end{array}$ & $\begin{array}{c}0.092 \\
{[0.017]^{* *}}\end{array}$ & $\begin{array}{c}0.221 \\
{[0.021]^{* *}}\end{array}$ & $\begin{array}{c}0.267 \\
{[0.012]^{* *}}\end{array}$ \\
\hline $\begin{array}{l}\text { P-value } \\
(<\text { tertiary })\end{array}$ & 0.07 & 0 & 0 & 0 & 0.01 & 0 & 0.73 & 0 & 0 & 0.2 & 0.03 & 0.33 & 0.5 \\
\hline \multicolumn{14}{|c|}{ Tertiary } \\
\hline $26-35$ & $\begin{array}{c}0.176 \\
{[0.019]^{* *}}\end{array}$ & $\begin{array}{c}0.06 \\
{[0.021]^{* *}}\end{array}$ & $\begin{array}{c}0.061 \\
{[0.015]^{* *}}\end{array}$ & $\begin{array}{c}0.061 \\
{[0.013]^{* *}}\end{array}$ & $\begin{array}{c}0.042 \\
{[0.021]^{*}}\end{array}$ & $\begin{array}{c}0.095 \\
{[0.029]^{* *}}\end{array}$ & $\begin{array}{c}0.05 \\
{[0.017]^{* *}}\end{array}$ & $\begin{array}{c}0.023 \\
{[0.011]^{*}}\end{array}$ & $\begin{array}{c}0.023 \\
{[0.022]}\end{array}$ & $\begin{array}{c}0.053 \\
{[0.024]^{*}}\end{array}$ & $\begin{array}{c}0.086 \\
{[0.016]^{* *}}\end{array}$ & $\begin{array}{c}0.044 \\
{[0.015]^{* *}}\end{array}$ & $\begin{array}{c}0.1 \\
{[0.016]^{* *}}\end{array}$ \\
\hline $36-45$ & $\begin{array}{c}0.122 \\
{[0.023]^{* *}}\end{array}$ & $\begin{array}{c}0.093 \\
{[0.020]^{* *}}\end{array}$ & $\begin{array}{c}0.058 \\
{[0.014]^{* *}}\end{array}$ & $\begin{array}{c}0.033 \\
{[0.013]^{* *}}\end{array}$ & $\begin{array}{c}0.048 \\
{[0.029]^{+}}\end{array}$ & $\begin{array}{c}0.078 \\
{[0.022]^{* *}}\end{array}$ & $\begin{array}{c}0.043 \\
{[0.014]^{* *}}\end{array}$ & $\begin{array}{c}0.014 \\
{[0.011]}\end{array}$ & $\begin{array}{c}0 \\
{[0.018]}\end{array}$ & $\begin{array}{c}0.036 \\
{[0.022]^{+}}\end{array}$ & $\begin{array}{c}0.025 \\
{[0.023]}\end{array}$ & $\begin{array}{c}0.034 \\
{[0.016]^{*}}\end{array}$ & $\begin{array}{c}0.11 \\
{[0.016]^{* *}}\end{array}$ \\
\hline $46-55$ & $\begin{array}{c}0.083 \\
{[0.025]^{* *}}\end{array}$ & $\begin{array}{c}0.09 \\
{[0.020]^{* *}}\end{array}$ & $\begin{array}{c}0.083 \\
{[0.014]^{* *}}\end{array}$ & $\begin{array}{c}0.041 \\
{[0.014]^{* *}}\end{array}$ & $\begin{array}{c}0.025 \\
{[0.029]}\end{array}$ & $\begin{array}{c}0.046 \\
{[0.018]^{* *}}\end{array}$ & $\begin{array}{c}0.039 \\
{[0.019]^{*}}\end{array}$ & $\begin{array}{c}0.013 \\
{[0.013]}\end{array}$ & $\begin{array}{c}0.009 \\
{[0.020]}\end{array}$ & $\begin{array}{c}0.014 \\
{[0.022]}\end{array}$ & $\begin{array}{c}0.026 \\
{[0.017]}\end{array}$ & $\begin{array}{l}-0.016 \\
{[0.018]}\end{array}$ & $\begin{array}{c}0.059 \\
{[0.015]^{* *}}\end{array}$ \\
\hline $56-65$ & $\begin{array}{c}0.038 \\
{[0.044]}\end{array}$ & $\begin{array}{c}0.016 \\
{[0.023]}\end{array}$ & $\begin{array}{c}0.098 \\
{[0.019]^{* *}}\end{array}$ & $\begin{array}{c}0.046 \\
{[0.022]^{*}}\end{array}$ & $\begin{array}{c}0.003 \\
{[0.042]}\end{array}$ & $\begin{array}{c}0.062 \\
{[0.027]^{*}}\end{array}$ & $\begin{array}{c}0.038 \\
{[0.022]^{+}}\end{array}$ & $\begin{array}{c}0.004 \\
{[0.017]}\end{array}$ & $\begin{array}{c}0.063 \\
{[0.024]^{* *}}\end{array}$ & $\begin{array}{c}0.037 \\
{[0.022]^{+}}\end{array}$ & $\begin{array}{c}0.059 \\
{[0.021]^{* *}}\end{array}$ & $\begin{array}{c}0.007 \\
{[0.023]}\end{array}$ & $\begin{array}{c}0.038 \\
{[0.023]^{+}}\end{array}$ \\
\hline $\begin{array}{l}\text { P-value } \\
\text { (tertiary) }\end{array}$ & 0 & 0.01 & 0.19 & 0.42 & 0.76 & 0.38 & 0.95 & 0.78 & 0.1 & 0.58 & 0.02 & 0.04 & 0 \\
\hline Selectivity & $\begin{array}{c}0.085 \\
{[0.092]}\end{array}$ & $\begin{array}{c}0.521 \\
{[0.098]^{* *}}\end{array}$ & $\begin{array}{c}0.437 \\
{[0.067]^{* *}}\end{array}$ & $\begin{array}{c}0.705 \\
{[0.081]^{* *}}\end{array}$ & $\begin{array}{c}0.671 \\
{[0.127]^{* *}}\end{array}$ & $\begin{array}{c}0.454 \\
{[0.115]^{* *}}\end{array}$ & $\begin{array}{c}-0.173 \\
{[0.116]}\end{array}$ & $\begin{array}{c}0.981 \\
{[0.078]^{* *}}\end{array}$ & $\begin{array}{c}0.707 \\
{[0.110]^{* *}}\end{array}$ & $\begin{array}{c}0.553 \\
{[0.087]^{* *}}\end{array}$ & $\begin{array}{c}0.572 \\
{[0.086]^{* *}}\end{array}$ & $\begin{array}{c}0.390 \\
{[0.086]^{* *}}\end{array}$ & $\begin{array}{c}0.488 \\
{[0.103]^{* *}}\end{array}$ \\
\hline
\end{tabular}

[Robust standard errors in brackets] ${ }^{+}$significant at $10 \% ;{ }^{*}$ significant at $5 \% ;{ }^{* *}$ significant at $1 \%$

Notes: Sample includes all individuals between 26 and 65 years of age. Dependent variable is the normalized average literacy skill test score. Control variables are age, age squared, country-specific ability, and a country-specific indicator for female. School's contributions to literacy skills for different cohorts are the coefficient estimates on the interactive terms between school education (measure by years of education at primary and secondary schools) and indicators for the respective age cohorts. College's contributions to literacy skills for different cohorts are the coefficient estimates on the interactive terms between college

education (measure by years of education at tertiary schools) and indicators for the respective age cohorts. P-value (<tertiary) and p-value (tertiary) are for the Ftests that years of school less than tertiary and tertiary contribute the same over the four cohorts to literacy skill. 


\section{References}

Altonji, Joseph G., and Charles R. Pierret. 2001. "Employer learning and statistical discrimination." Quarterly Journal of Economics 116,no.1 (February):313-350.

Ashenfelter, Orley, and Alan B. Krueger. 1994. American Economic Review 84,no.5 (December):1157-1173.

Cameron, Stephen V., and James J. Heckman. 1993. "The nonequivalence of high school equivalents." Journal of Labor Economics 11,no.1,Part 1 (January):1-47.

Card, David. 1999. "Causal effect of education on earnings." In Handbook of labor economics, edited by Orley Ashenfelter and David Card. Amsterdam: North-Holland:1801-1863.

Card, David, and Alan B. Krueger. 1992. "Does school quality matter? Returns to education and the characteristics of public schools in the United States." Journal of Political Economy 100,no.1 (February):1-40.

Hanushek, Eric A. 2003. "The failure of input-based schooling policies." Economic Journal 113,no.485 (February):F64-F98.

Hanushek, Eric A., Steven G. Rivkin, and Lori L. Taylor. 1996. "Aggregation and the estimated effects of school resources." Review of Economics and Statistics 78,no.4 (November):611627.

Harmon, Colm, Hessel Oosterbeek, and Ian Walker. 2003. "The returns to education: Microeconomics." Journal of Economic Surveys 17,no.2:115-155.

Heckman, James J., Anne Layne-Farrar, and Petra Todd. 1996. "Human capital pricing equations with an application to estimating the effect of schooling quality on earnings." Review of Economics and Statistics 78,no.4 (November):562-610.

Katz, Lawrence F., and Kevin M. Murphy. 1992. "Changes in relative wages, 1963-1987: Supply and demand factors." Quarterly Journal of Economics 107,no.1 (February):35-78.

Lazear, Edward P. 2003. "Teacher incentives." Swedish Economic Policy Review 10,no.3:179-214.

Lowe, Roy, ed. 1992. Education and the second world war: Studies in schooling and social change. London: Falmer Press.

Mincer, Jacob. 1970. "The distribution of labor incomes: a survey with special reference to the human capital approach." Journal of Economic Literature 8,no.1 (March):1-26. 1974. Schooling Experience and Earnings. New York: NBER.

Mulligan, Casey B. 1999. "Galton versus the human capital approach to inheritance." Journal of Political Economy 107,no.6, pt. 2 (December):S184-S224. 
Murnane, Richard J., John B. Willett, Yves Duhaldeborde, and John H. Tyler. 2000. "How important are the cognitive skills of teenagers in predicting subsequent earnings?" Journal of Policy Analysis and Management 19,no.4 (Fall):547-568.

Murphy, Kevin M., and Finis Welch. 1992. "The structure of wages." Quarterly Journal of Economics 107,no.1 (February):285-326.

Murray, T. Scott, Irwin S. Kirsch, and Lynn B. Jenkins, eds. 1997. Adult Literacy in OECD Countries: Technical Report on the First International Adult Literacy Survey. Washington: National Center for Education Statistics.

National Center for Education Statistics. 2005. NAEP 2004: Trends in Academic Progress, Three Decades of Student Performance in Reading and Mathematics. Washington, D. C.: U.S. Department of Education.

Organisation for Economic Co-operation and Development. 1995. OECD Education Statistics, 1985-92. Paris, France: Organisation for Economic Co-operation and Development

- 2005. Education at a Glance: OECD Indicators 2005. Paris, France: Organisation for Economic Co-operation and Development

Psacharopoulos, George. 1994. "Returns to investment in education: A global update." World Development 22:1325-1344.

Psacharopoulos, George, and Harry A. Patrinos. 2004. "Returns to investment in education: a further update." Education Economics 12,no.2 (August):111-134.

Smith, Jacqui, and Michael Marsiske. 1997. "Definitions and taxonomies of foundation skills and adult competencies." In Adult basic skills: Innovations in measurement and policy analysis, edited by Albert Tuijnman, Irwin S. Kirsch and Daniel A. Wagner. Cresskill, NJ: Hampton Press.

Tyler, John H., Richard J. Murnane, and John B. Willett. 2000. "Estimating the labor market signalling vlaue of the GED." Quarterly Journal of Economics 115,no.2 (May):431-468.

U.S. Office of Education. 1945. Education under enemy occupation in Belgium, China, Czechoslovakia, Greece, Luxemburg, Netherlands, Norway, Poland. Washington: Federal Security Agency, U.S. Office of Educaiton

Wolff, Richard J. 1992. "Italian education during world war II: Remnants of failed fascist education, seeds of the new schools." In Education and the second world war: Studies in schooling and social change, edited by Roy Lowe. London: Falmer Press:chapter 6. 